\title{
ANALISIS KINERJA KEUANGAN PADA PERUSAHAAN PT. MUSTIKA RATU TBK. BERDASARKAN ANALISIS RASIO LIKUIDITAS, SOLVABILITAS, DAN RENTABILITAS
}

\author{
Asih Nurati, Burhanudin, Ratna Damayanti \\ Fakultas Ekonomi, Universitas Islam Batik Surakarta \\ Jl. KH Agus Salim No.10 Surakarta \\ Email : asih.nur9364@gmail.com
}

\begin{abstract}
This study is intended to determine the financial performance of PT Mustika Ratu Tbk. by analyzing financial data through financial ratios of liquidity, solvency and profitability. The data analyzed are company financial statements which include Balance Sheet, Profit / Loss, Cash Flow PT Mustika Ratu Tbk. 2015 to 2017. This research is a quantitative research, processed data, namely financial report data of PT Mustika Ratu Tbk. taken through data on the Indonesia Stock Exchange. Financial data taken is annual reports from 2015 to 2017. Analysis of this data uses liquidity ratios, solvency ratios, profitability ratios.
\end{abstract}

Key Word : Kinerja Keuangan, Rasio Keuangan

\section{PENDAHULUAN}

Pertumbuhan, prospek, masa depan, serta potensi perkembangan yang baik dalam perusahaan dapat dilihat melalui kinerja keuangan yang dimiliki oleh suatu perusahaan. Di masa depan pasti akan diperlukan informasi kinerja keuangan yang telah dijalani pada masa sekarang atau terdahulu, untuk meninjau ulang perbaikan apa yang diperlukan dalam memajukan sumber daya ekonomi sebuah perusahaan.(Barlian, 2003). Sebuah perusahaan bisa dinyatakan mempunyai kinerja yang baik jika mempunyai tingkat kesehatan keuangan yang baik pula. Kinerja suatu perusahaan khususnya dalam bidang keuangan merupakan salah satu pedoman masyarakat permodal dalam memilih perusahaan yang akan digunakan untuk penanaman sahamnya. Data keuanganyang disajikan perusahaan harus menunjukkan kinerja keuangan yang sehat dan baik kepada para pemegang saham secara berkala. Dengan data keuangan yang disajikan maka akan terihat jelas bagaimana kondisi keuangan perusahaan tersebut, sehingga pemegang saham tidak khawatir jika sewaktu-waktu perusahaan tersebut akan pailit atau bangkrut.

Perencanaan yang tepat dalam mengelola perusahaan merupakan salah satu pedoman keberhasilan manajer. Seorang manajer harus bisa membuat perencanaan keuangan yang benar sesuai latar belakang yang dimiliki perusahaan. Analisa rasio merupakan salah satu bentuk pembuat perencanaan serta pengendalian keuangan yang baik. (Setyani, 2005). Kinerja keuangan suatu periode tertentu atau kondisi keuangan suatu perusahaan dapat dilihat melalui rasio keuangan. 
Perusahaan secara periodik tertentu mengeluarkan sebuah laporan perusahaan yang diberikan kepada pihak yang menanamkan saham maupun pemilik perusahaan, misalnya pemilik perusahaan, kreditor, pemerintah,dan pihak manajemen itu sendiri. Sebuah laporan keuangan perusahaan disajikan kepada pihak-pihak yang berkepentingan dengan tujuan memberikan informasi tentang kondisi keuangan,kinerja keuangan dan arus kas dalam periode waktu tertentu.

Sebuah informasi laporan keuangan itu diharapkan bermanfaat bagi pihak-pihak berkepentingan dalam mengambil sebuah keputusan. Selain itu, informasi laporan keuangan tersebut berguna untuk memberikan gambaran sebuahperusahaan sudah memenuhi standar kinerja atau belum memenuhi standar kinerja. Kinerja keuangan yang dimiliki perusahaan diketahui dengan cara melakukan analisa keuangan.

Analisa rasio merupakan sebuah cara mengetahui suatu kondisi keuangan dalam keadaan baik atau dalam keadaan buruk. Analisa rasiokeuangan digunakan untuk mengetahui kesehatan kinerja keuangan sebuah perusahaan. Untuk menganalisa keuangan tersebut dibutuhkan laporan keuangan perusahaan minimal 2 (dua) tahun terakhir.

\section{TINJAUAN TEORITIS}

\section{KinerjaKeuangan}

Kinerja keuangan merupakan analisa keuangan yang digunakan untuk mengukur dan melihat perkembangan keuangan yang dimiliki oleh suatu perusahaan dengan diukur dari suatu aturan keuangan secara benar. Sucipto (2003), kinerja keuangan merupakan keberhasilan sebuah perusahaan dalam mendapatkan keuntungan yang ditentukan melalui ukuran tertentu yang menjadi tolak ukur keberhasilan suatu perusahaan.

Untuk bisa bersaing baik dengan perusahaan dibidang yang sama, perusahaan perlu melakukan pengukuran kinerja keuangan. Pada suatu periode tertentu perusahaan dapat melakukan analisa kinerja keuangan yang menjadi salah satu proses pengukuran secara kritis terhadap data keuangan yang dimiliki oleh suatu perusahaan .

Dalam buku Munawir (2012:31) menyatakan, pengukuran kinerja keuangan mempunyai tujuan :

a) Untuk mengetahui tingkat rentabilitas

b) Mengetahui tingkat stabilitas

c) Mengetahui tingkat likuiditas.

d) Mengetaui tingkat solvabilitas

\section{Laporan Keuangan}

Harahap (2009: 105) menuturkan bahwa laporankeuangan merupakan gambaran suatu posisi keuangan yang dimiliki oleh sebuah perusahaan. Gitman (2012: 44) menuturkan bahwa sebuah laporankeuangan yang dimiliki oleh perusahaan harus diserahkan kepada pihak pemegang saham selama satu tahun terakhir yang berjalan. Ikatan Akuntan Indonesia(2009: 3), menyatakan bahwa laporan keuangan bertujuan untuk memberikan info tentang posisi keuangan perusahaan, kinerja, serta laporan keuangan suatu perusahaan yangberguna untuk pihak-pihak yang berkepentingan dalam pengambilan keputusanekonomi. 


\section{Analisis Rasio Keuangan}

Suatu perusahaan akan menganalisa keuangannya dengan berbagai cara, salah satunya yaitu dengan analisa rasio. Sofyan Syafri H (2011:297), menyatakan bahwa rasio keuangan merupakan angka yang didapat dari perbandingan suatu laporan denganlaporan keuangan lainnya yang memiliki hubungan relevan dan signifikan.

Rasio keuangan dibagi dalam tiga bentuk yaitu :

Rasio Likuiditas

Rasio keuangan yangdipergunakan sebagai pengukur kemampuansebuah perusahaan untuk mencukupi kebutuhan hutang jangka pendek yang dimiliki perusahaan. Rasio likuiditas terdiri dari Current Ratio(Rasio Lancar), Quick Ratio(Rasio Cepat),Cash Ratio(Rasio Lambat).

$>$ Rasio Solvabilitas

Merupakan rasio yang digunakan untuk menilai perbandingan modal yang dimiliki oleh pemilik perusahaan dengan kewajiban yang dikredit dari pihak bank atau penjamin..

Rasio Solvabilitas terdiri dari : TotalDebt to EquityRatio, TotalDebt to TotalAsset Ratio.

$>$ Rasio Rentabilitas (Profitabilitas)

Merupakan rasio yang dipergunakan sebagai pengukur kemampuan suatu perusahaan untuk mendapatkan keuntungan.Rasio ini terdiri dari :Gross Profit Margin, Net Profit Margin, Return on Equity, Return on Asset, dan Operating Profit Margin.

\section{Kerangka Pemikiran}

Adapun kerangka pemikiran analasia ini yaitu :

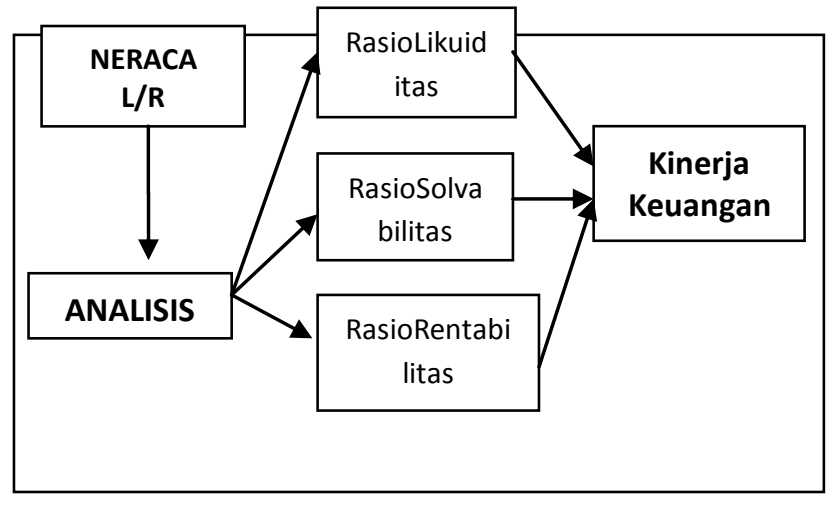

\section{METODEPENELITIAN}

\section{ObjekPenelitian}

Objek penelitian yang dipilih oleh penulis yaitu kinerja keuangan sebuah perusahaan jamu dan kecantikan yang telah terdaftar di BEI Mustika Ratu, Tbk yang akan dianalisis 
berdasarkan rasio keuangan. Yang digunakan untuk menganalisa rasio keuangan diantaranya : rasiolikuiditas, solvabilitas, dan rentabilitas periode $2015-2017$.

\section{Unit Penelitian}

Unit penelitian yang dipilih oleh penulis sesuai dengan permasalahan yang diteliti yaitu tentang kinerjakeuangan sebuah perusahaan kosmetik yang diambil berdasarkan laporankeuangan tahunan PT Mustika Ratu, Tbk periode 2015-2017.

\section{Jenis Data}

Dalam penelitian ini penulis menggunakan dua jenis data yakni kuantitatif dan kualitatif. Data berupa sejumlah angka yang menunjukkan jumlah sesuatu, yaitu laporan keuangan sebuah perusahaan yang berupa neraca dan laporan laba rugi merupakan jenis data kuantitatif. Sedangkan data yang tidak ditunjukkan dalam bentukangka, misalnya sejarah berdirinya perusahaan serta bidang usaha yang digelutiperusahaan tersebut disebut dengan data kualitatif.

\section{Teknik PengumpulanData}

Teknik pengumpulan data yang dipakai yaitu:

a. Field Work Research, yaitu pengumpulan data melalui penelitian yang dilakukan di perusahaan yang dijadikan obyek penelitian, meliputi pengambilan data keuangan (neraca dan laba rugi) yang diambil dari data Bursa Efek Indonesia.

b. Library Research, yaitu pengumpulan data melalui penelitian yang dilakukan di perpustakaan dengan cara mencari literatur atau materi yang berhubungan dengan penelitian.

\section{Teknik Analisa Data}

Penulis menggunakan teknik analisa data rasio keuangan, yaitu Likuiditas, Solvabilitas, dan Rentabilitas.

\section{1) Rasio Likuiditas}

Merupakan rasio yang dipergunakan sebagai pengukur kemampuan sebuah perusahaan dalam memenuhi kebutuhan hutang jangka pendek yang dimiliki perusahaan. Rasio likuiditas ditentukan dengan tiga cara yaitu :

a. Current Ratio (Rasio Lancar)

$$
\text { Rasio Lancar }=\frac{\text { AktivaLancar } \times 100 \%}{\text { HutangLancar }}
$$

b. Quick Ratio (Rasio Cepat)

Rasio Cepat $=\underline{\text { AktivaLancar }- \text { Persediaan } \times 100 \%}$ HutangLancar

c. Cash ratio (Rasio Kas)

$$
\text { Rasio Kas }=\frac{\text { Kas+Efekx } 100 \%}{\text { HutangLancar }}
$$




\section{2) Rasio Solvabilitas}

Merupakan rasio yang digunakan untuk mengukur perbandingan modal yang disediakan pemiliknya dengan dana yang dipinjam dari kreditur perusahaan tersebut. Rasio solvabiltas terdiri dari :

a. TotalDebt to Total AssetRatio

$$
\text { DTAR }=\frac{\text { JumlahHutang x 100\% }}{\text { JumlahAktiva }}
$$

b. TotalDebt to EquityRatio

$$
\text { DTER }=\frac{\text { JumlahHutang } \times 100 \%}{\text { Ekuitas }}
$$

\section{3) Rasio Rentabilitas}

Merupakan rasio yang digunakan untuk mengukur kemampuan perusahaan dalam memperoleh laba, rentabilitas perusahaan digunakan untulk mewujudkan perbandingan antara keuntungan dengan aktiva atau modal yang menghasilkan laba tersebut.

Rasio Rentabilitas terdiri dari :

a. Rentabilitas Ekonomi (ROA)

$$
\text { ROA }=\frac{\text { EBIT } \times 100 \%}{\text { JumlahAktiva }}
$$

b. Rentabilitas Modal Sendiri (ROE)

$$
\text { ROE }=\frac{\text { Laba Bersih Setelah Pajak x100\% }}{\text { Ekuitas }}
$$

c. GrossProfitMargin (GPM)

$$
G P M=\frac{\text { LabaKotor } \mathrm{x} 100 \%}{\text { PenjualanBersih }}
$$


d. NetProfitMargin (NPM)

$$
N P M=\frac{\text { LabaBersih x } 100 \%}{\text { PenjualanBersih }}
$$

e. OperatingProfitMargin (OPM)

$$
O P M=\frac{\text { Laba Usaha } \times 100 \%}{\text { Penjualan Bersih }}
$$

\section{HASIL PENELITIAN DAN PEMBAHASAN}

Penulis menganalisis data keuangan PT Mustika Ratu TBK dengan menggunakan analisis rasio keuangan, diantaranya yaitu rasio likuiditas, solvabilitas, dan rentabilitas.

1) Rasio Likuiditas

a. Current Ratio (RasioLancar)

Hasil dari perhitungan Current Ratio ditunjukkan oleh tabel berikut.

Tabel 1 Current Ratio PT Mustika Ratu Tbk tahun 2015-2017

\begin{tabular}{|c|c|c|c|c|c|}
\hline Tahun & Aktiva Lancar & Hutang Lancar & CR & Standar & Kriteria \\
\hline 2015 & 380.988 .168 .593 & 102.898 .339 .772 & $370,26 \%$ & $>200 \%$ & Likuid \\
\hline 2016 & 372.731 .501 .477 & 93.871 .952 .310 & $397,06 \%$ & $>200 \%$ & Likuid \\
\hline 2017 & 384.262 .906 .538 & 106.813 .922 .324 & $359,75 \%$ & $>200 \%$ & Likuid \\
\hline
\end{tabular}

Sumber : Data Sekunder 2015-2017 diolah

b. Quick Ratio (Rasio Cepat)

Hasil perhitungan Quick Ratio disajikan pada table berikut.

Tabel 2 Quick Ratio PT Mustika Ratu Tbl. Tahun 2015 - 2017

\begin{tabular}{|c|c|c|c|c|c|c|}
\hline \multirow{2}{*}{ Tahun } & AktivaLancar & Persediaan & HutangLancar & QR & Standar & Kriteria \\
\hline 2015 & 380.988 .168 .593 & 78.917 .127 .036 & 102.898 .339 .772 & $293,56 \%$ & $>150 \%$ & Likuid \\
\hline 2016 & 372.731 .501 .477 & 90.719 .293 .111 & 93.871 .952 .310 & $300,42 \%$ & $>150 \%$ & Likuid \\
\hline 2017 & 384.262 .906 .538 & 109.760 .005 .307 & 106.813 .922 .324 & $256,99 \%$ & $>150 \%$ & Likuid \\
\hline
\end{tabular}

Sumber : Data sekunder 2015-2017 diolah 
c. Cash Ratio (Rasio Kas)

Hasil perhitungan Cash Ratio disajikan pada table berikut.

Tabel 3 Cash Ratio PT Mustika Ratu Tbk. Tahun 2015-2017

\begin{tabular}{|c|c|c|c|c|c|}
\hline Tahun & Kas + Efek & HutangLancar & $\begin{array}{c}\text { Cash } \\
\text { Ratio }\end{array}$ & Standar & Kriteria \\
\hline 2015 & 36.273 .186 .840 & 102.898 .339 .772 & $35,25 \%$ & $>50 \%$ & Ilikuid \\
\hline 2016 & 24.376 .706 .961 & 93.871 .952 .310 & $25,97 \%$ & $>50 \%$ & Ilikuid \\
\hline 2017 & 22.853 .543 .946 & 106.813 .922 .324 & $21,40 \%$ & $>50 \%$ & Ilikuid \\
\hline
\end{tabular}

Sumber : Data sekunder 2015-2017 diolah

2) Rasio Solvabilitas

a. Total Debt to Total Asset Ratio (RasioUtang terhadap Aset)

Hasil perhitungan rasio utang terhadap asset disajikan pada table berikut.

Tabel 4 Rasio Utang terhadap Aset PT Mustika Ratu Tbk. periode 2015-2017

\begin{tabular}{|c|c|c|c|c|c|}
\hline Tahun & Jumlah Hutang & Jumlah Aktiva & DAR & Standar & Kriteria \\
\hline 2015 & 120.064 .018 .299 & 497.090 .038 .108 & $24,15 \%$ & $<35 \%$ & Solvabel \\
\hline 2016 & 113.947 .973 .889 & 483.037 .173 .864 & $23,59 \%$ & $<35 \%$ & Solvabel \\
\hline 2017 & 130.623 .005 .085 & 497.354 .419 .089 & $26,26 \%$ & $<35 \%$ & Solvabel \\
\hline
\end{tabular}

Sumber : Data sekunder 2015 - 2017 diolah

b. Total Debt to Equity Ratio (Rasio Utang terhadap Modal)

Hasil perhitungan TotalDebt to EquityRatio disajikan pada tabel berikut.

Tabel 5 Rasio Utang terhadap Modal PT Mustika Ratu Tbk. tahun 2015-2017

\begin{tabular}{|c|c|c|c|c|c|}
\hline Tahun & JumlahHutang & Ekuitas & DER & Standar & Kriteria \\
\hline 2015 & 120.064 .018 .299 & 377.026 .019 .809 & $31,85 \%$ & $<80 \%$ & Solvabel \\
\hline 2016 & 113.947 .973 .889 & 369.089 .199 .975 & $30,87 \%$ & $<80 \%$ & Solvabel \\
\hline 2017 & 130.623 .005 .085 & 366.731 .414 .004 & $35,62 \%$ & $<80 \%$ & Solvabel \\
\hline
\end{tabular}

Sumber : Data sekunder 2015-2017 diolah 


\section{3) Rasio Rentabilitas}

a. Rasio Pengembalian Aset (Return on Assets Ratio)

Hasil perhitungan rasio pengembalian asset disajikan pada table berikut.

Tabel 6 Rasio pengembalian asset PT Mustika Ratu Tbk tahun 2015-2017

\begin{tabular}{|c|c|c|c|c|c|}
\hline Tahun & EBIT & Jumlah Aktiva & $R O A$ & Standar & Kriteria \\
\hline 2015 & 2.255 .976 .429 & 497.090 .038 .108 & $0,45 \%$ & $>30 \%$ & Kurang Efisien \\
\hline 2016 & $(4.082 .301 .885)$ & 483.037 .173 .864 & $\begin{array}{c}- \\
0,85 \%\end{array}$ & $>30 \%$ & Kurang Efisien \\
\hline 2017 & $(1.355 .570 .984)$ & 497.354 .419 .089 & $\begin{array}{c}- \\
0,27 \%\end{array}$ & $>30 \%$ & Kurang Efisien \\
\hline
\end{tabular}

Sumber : Data sekunder 2015-2017 diolah

b. Rasio Pengembalian Ekuitas (Return on Equity Ratio)

Hasil perhitungan Return on Equty Ratio disajikan pada table berikut :

Tabel 7 Return on Equty Ratio PT Mustika Ratu Tbk. 2015-2017

\begin{tabular}{|c|c|c|c|c|c|}
\hline Tahun & $\begin{array}{c}\text { Laba Bersih } \\
\text { Setelah Pajak }\end{array}$ & Ekuitas & ROE & Standar & Kriteria \\
\hline 2015 & 1.045 .990 .311 & 377.026 .019 .809 & $0,28 \%$ & $>40 \%$ & Kurang Efisien \\
\hline 2016 & $(5.549 .465 .678)$ & 369.089 .199 .975 & $-1,50 \%$ & $>40 \%$ & Kurang Efisien \\
\hline 2017 & $(1.283 .332 .109)$ & 366.731 .414 .004 & $-0,35 \%$ & $>40 \%$ & Kurang Efisien \\
\hline
\end{tabular}

Sumber : Data sekunder 2015-2017 diolah

c. Gross Profit Margin (Margin Laba Kotor)

Hasil perhitungan Gross Profit Margin disajikan pada tabel berikut.

Tabel 8 Gross Profit Margin PT Mustika Ratu Tbk. tahun 2015-2017

\begin{tabular}{|c|c|c|c|c|c|}
\hline Tahun & Laba Kotor & $\begin{array}{c}\text { Penjualan } \\
\text { Bersih }\end{array}$ & GPM & Standar & Kriteria \\
\hline 2015 & 246.545 .606 .138 & 428.092 .732 .505 & $57,59 \%$ & $>30 \%$ & Efisien \\
\hline 2016 & 202.098 .310 .596 & 344.361 .345 .265 & $58,69 \%$ & $>30 \%$ & Efisien \\
\hline 2017 & 199.569 .393 .598 & 344.678 .666 .245 & $57,90 \%$ & $>30 \%$ & Efisien \\
\hline
\end{tabular}

Sumber: Data sekunder 2015-2017 diolah 
d. Net Profit Margin

Hasil perhitungan Net Profit Margin disajikan pada tabel berikut.

Tabel 9 Net Profit Margin PT Mustika Ratu Tbk tahun 2015-2017

\begin{tabular}{|c|c|c|c|c|c|}
\hline Tahun & Laba Bersih & $\begin{array}{c}\text { Penjualan } \\
\text { Bersih }\end{array}$ & $N P M$ & Standar & Kriteria \\
\hline 2015 & $(1.929 .395 .640)$ & 428.092 .732 .505 & $\begin{array}{c}- \\
0,45 \%\end{array}$ & $>20 \%$ & Kurang Efisien \\
\hline 2016 & $(7.936 .819 .834)$ & 344.361 .345 .265 & $\begin{array}{c}- \\
2,30 \%\end{array}$ & $>20 \%$ & Kurang Efisien \\
\hline 2017 & $(2.357 .785 .971)$ & 344.678 .666 .245 & $\begin{array}{c}- \\
0,68 \%\end{array}$ & $>20 \%$ & Kurang Efisien \\
\hline
\end{tabular}

Sumber: Data sekunder 2015-2017 diolah

e. Operating Profit Margin

Hasil perhitungan Operating Profit Margin disajikan pada tabel berikut.

Tabel 10. Operating Profit Margin PT Mustika ratu Tbk tahun 2015-2017

\begin{tabular}{|c|c|c|c|c|c|}
\hline Tahun & Laba Usaha & $\begin{array}{c}\text { Penjualan } \\
\text { Bersih }\end{array}$ & OPM & Standar & Kriteria \\
\hline 2015 & 5.238 .755 .780 & 428.092 .732 .505 & $1,22 \%$ & $>20 \%$ & Kurang Efisien \\
\hline 2016 & 173.216 & 344.361 .345 .265 & $0,00 \%$ & $>20 \%$ & Kurang Efisien \\
\hline 2017 & 3.645 .061 .742 & 344.678 .666 .245 & $1,06 \%$ & $>20 \%$ & Kurang Efisien \\
\hline
\end{tabular}

Sumber: Data sekunder 2015-2017 diolah

\section{PEMBAHASAN}

Hasil dari analisa data diatas secara keseluruhan Rasio Likuiditas berada dalam kondisi likuid karena memiliki nilai current ratio $>200 \%$, nilai quick ratio $>150 \%$, dan nilai cash ratio termasuk illikuid karena nilai rasio sebesar $<50 \%$.

Rasio Solvabilitas. berada dalam kondisi solvabel karena memiliki nilai debt to asset $<35 \%$, dan debt to equity $<80 \%$.

Rasio Profitabilitas berada dalam kondisi kurang efisien karena memiliki nilai return on asset $<30 \%$, return on equity $<40 \%$, net profit margin $<20 \%$, operating profit margin $<20 \%$ dan gross profit margin dalam kondisi yang efisien yaitu mempunyai nilai $>30 \%$. 


\section{KESIMPULAN DAN SARAN}

\section{Kesimpulan}

Berdasarkan analisis data keuangan PT Mustika Ratu Tbk. tahun 2015 hingga 2017 diperoleh kesimpulan sebagai berikut :

1. Rasio Likuiditas PT Mustika Ratu Tbk. berada dalam kondisi likuid karena memiliki nilai current ratio $>200 \%$, nilai quick ratio $>150 \%$, dan nilai cash ratio termasuk illikuid karena nilai rasio sebesar $<50 \%$.

2. Rasio Solvabilitas PT Mustika Ratu Tbk. berada dalam kondisi solvabel karena memiliki nilai debt to asset $<35 \%$, dan debt to equity $<80 \%$.

3. Rasio Profitabilitas PT Mustika Ratu Tbk. berada dalam kondisi kurang efisien karena memiliki nilai return on asset $<30 \%$, return on equity $<40 \%$, net profit margin $<20 \%$, operating profit margin $<20 \%$ dan gross profit margin dalam kondisi yang efisien yaitu mempunyai nilai $>30 \%$.

\section{Saran}

Hasil analisis rasio rentabilitas terutama pada net profit margin menunjukkan bahwa laba/rugi bersih setelah pajak selama tahun 2015 hingga 2017 mengalami kerugian secara terus menerus. Terutama pada tahun 2016 yang mengalami kerugian hampir 8.000.000.000,00. Oleh karena itu disarankan bagi perusahaan untuk memperbaiki kinerja perusahaannya terutama pada bidang penjualan. Peningkatan penjualan pada produk - produk PT Mustika ratu Tbk diharapkan dapat menutup kerugian - kerugian yang dialami pada tahun 2017 dan tahun - tahun sebelumnya.

\section{DAFTAR PUSTAKA}

Pongoh, 2013. Analisis Laporan Keuangan Untuk Menilai Kinerja Keuangan PT.BUMI RESOURCES TBK.

Maith, 2013. Analisis Laporan Keuangan Dalam Mengukur Kinerja Keuangan Pada PT.Hanjaya Mandala Sampoerna TBK.

Alexander, Ottay. 2015. Analisis Laporan Keuangan Untuk Menilai Kinerja Keuangan Pada PT. BPR CITRA DUMOGA MANADO.

Walandouw, Sabijono. 2015. Analisis Laporan Keuangan Dalam Mengukur Kinerja Keuangan Pada PT. BANK ARTHA GRAHA INTERNASIONAL, TBK.

Setyani, Meriewaty. 2005. Analisis Rasio Keuangan Terhadap Perubahan Kinerja Pada Perusahaan di Industri Food and Beverages yang terdaftar di BEJ. 
Mery, 2017. Pengaruh Likuiditas, Leverage Dan Profitabilitas Terhadap Nilai Perusahaan Dengan Kebijakan Dividen Sebagai Variabel Moderasi Pada Perusahaan Pertambangan Yang Terdaftar di BEI Tahun 2011-2014.

Arifati, Andini. 2016. Analisis Pengaruh Kualitas Auditor, likuiditas, Profitabilitas, Sovabilitas Dan Ukuran Perusahaan Terhadap Opini Audit going Concern Pada Perusahaan Manufaktur Yang Terdaftar di BEI.

Orniati, 2009. Laporan Keuangan sebagai Alat Untuk Menilai Kinerja Keuangan.

Susilawati, 2012. Analisis Perbandingan Pengaruh Likuiditas, Solvabilitas dan Profitabilitas Terhadap Harga Saham pada Perusahaan LQ 45.

Puuloh, 2016. Analisis Rasio Keuangan Untuk Menilai Kinerja Keuangan Perusahaan.

Rizal, 2017. Analisis Kinerja Keuangan PT. Garuda Indonesia Tbk`

https://www.academia.edu/9066297/PROFIL_USAHA_PT_MUSTIKA_RATU_Tbk?auto=downl oad

http://praisyliagabriela.blogspot.com/2013/09/profil-perusahaan-pt-mustika-ratu.html

https://tipsserbaserbi.blogspot.com/2016/03/macam-macam-rasio-keuangan-dan-rumusnya.html

https://www.jurnal.id/id/blog/2018-rasio-profitabilitas-pengertian-fungsi-jenis-dan-contoh-terlengkap 